\title{
Keefektifan pembelajaran matematika realistik ditinjau dari kemampuan pemodelan matematika dan prestasi belajar
}

\author{
Eki Rahmad ${ }^{1 *}$, Ariyadi Wijaya ${ }^{2}$ \\ ${ }^{1}$ SMA Negeri 2 Ranah Batahan, Pasaman Barat, Indonesia \\ 2 Department of Mathematics Education, Universitas Negeri Yogyakarta, Yogyakarta, Indonesia \\ * Corresponding Author. E-mail: ekirahmad37@yahoo.co.id
}

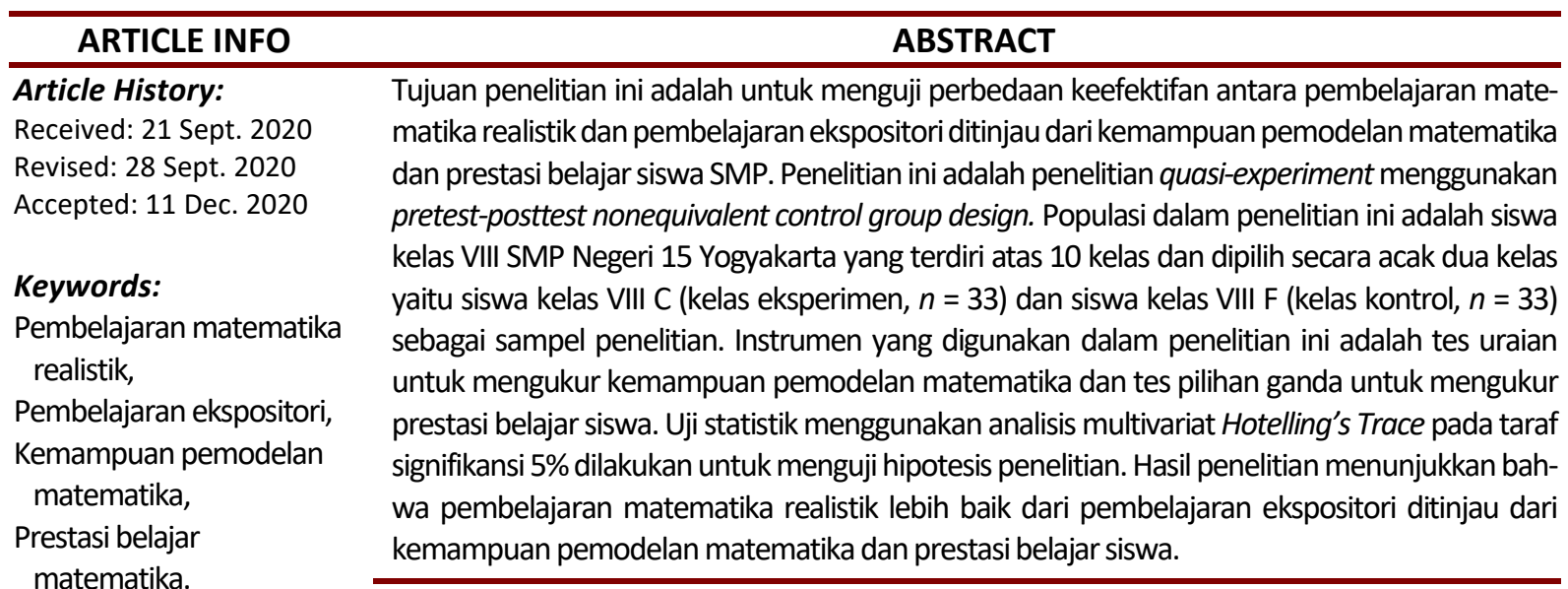

The purpose of this study was to examine the difference in effectiveness between realistic mathematics education and expository learning viewed from mathematical modelling competence and achievement of junior high school students. This study was quasi-experiment research with the pretest-posttest nonequivalent control group design. This study's population was the 8th-grade students of SMP Negeri 15 (junior high school) in Yogyakarta, Indonesia, consisting of ten classes. The sample in this study was the students of class VIII C (experiment group, $n=33$ ) and VIII $F$ (control group, $n=33$ ) selected randomly. In this study, the instruments used were essay questions to measure mathematics modelling competence and multiple-choice questions to measure learning achievement. Statistical test using the Manova with the Hotelling's Trace test at a significance level of 5\% was conducted to examine the hypothesis. The results showed that realistic mathematics education was better than expository learning viewed from students' $m a-$ thematics modelling competence and learning achievement.

This is an open access article under the CC-BY-SA license

\section{How to Cite:}

Rahmad, E., \& Wijaya, A. (2020). Keefektifan pembelajaran matematika realistik ditinjau dari kemampuan pemodelan matematika dan prestasi belajar. Pythagoras: Jurnal Pendidikan Matematika, 15(1), 100-110. https://doi.org/10.21831/pg.v15i1.34593

\section{PENDAHULUAN}

Matematika merupakan salah satu ilmu pengetahuan yang sangat berguna bagi kehidupan umat manusia. Oleh sebab itu, meraih prestasi pada pembelajaran matematika menjadi hal yang diinginkan oleh berbagai pihak, baik siswa sebagai peserta didik, guru sebagai fasilitator di kelas, maupun pemerintah sebagai pemangku dan pembuat kebijakan. Tentunya untuk mendapatkan prestasi yang baik membutuhkan usaha yang gigih dan juga kerja sama semua pihak, terutama antara guru dan siswa yang terlibat langsung di kelas.

Adanya capaian prestasi belajar yang baik, mengindikasikan berhasilnya proses pelaksanaan pembelajaran. Hal ini menggambarkan bahwa prestasi belajar dijadikan fokus utama pada pembelajaran. Fokus utama tersebut menghendaki seorang guru dapat mengidentifikasi faktor-faktor apa saja yang mempengaruhi prestasi belajar 
siswa. Setelah faktor-faktor tersebut teridentifikasi, diperlukan tindak lanjut agar tidak menjadi penyebab rendahnya prestasi belajar siswa.

Pada umumnya prestasi belajar matematika siswa di Indonesia termasuk kategori rendah dan memprihatinkan. Misalnya secara nasional, prestasi belajar matematika dapat dilihat dari rendahnya hasil ujian nasional. Contohnya seperti tahun ajaran 2013/2014 dimana rata-rata nasional pada mata pelajaran matematika tingkat SMP/ MTs adalah 60,90 dengan kategori C (Puspendik, 2014), tahun ajaran 2014/2015 perolehan rata-rata nasional pada mata pelajaran matematika sebesar 56,28 dengan kategori C (Puspendik, 2015), dan pada tahun ajaran 2015/2016 nilai rata-ratanya sebesar 50,24 dengan kategori D (Puspendik, 2016). Dengan demikian, rata-rata hasil ujian matematika SMP secara nasional cenderung mengalami penurunan dalam kurun waktu 2014 hingga 2016.

Secara internasional prestasi matematika siswa Indonesia juga tergolong rendah. Perolehan prestasi matematika siswa secara internasional dapat dilihat pada hasil Trends in International Mathematics and Science Study (TIMSS) dan Programme for International Student Assessment (PISA). Melihat pada hasil survei TIMSS, capaian prestasi matematika siswa Indonesia selalu di bawah nilai rata-rata internasional (Mullis et al., 2012). Sebagai contoh pada tahun 2011, dimana posisi Indonesia berada pada urutan 38 dari 45 negara peserta dengan capaian nilai rata-rata sebesar 386 sedangkan rata-rata internasional sebesar 500, tahun 2007 posisi Indonesia urutan 36 dari 49 negara peserta dengan nilai rata-rata sebesar 397 sedangkan rata-rata internasional sebesar 500 . Hasil yang serupa juga terlihat pada survei PISA. Contohnya pada tahun 2012 posisi Indonesia urutan 64 dari 65 peserta dengan perolehan nilai sebesar 375, sedangkan nilai rata-rata internasional yaitu sebesar 494 (OECD, 2014). Tahun 2009, posisi Indonesia berada pada urutan 57 dari 65 peserta dengan skor rata-rata sebesar 402, sedangkan skor rata-rata internasional sebesar 493 (OECD, 2010).

Rendahnya prestasi belajar di Indonesia menjadi sebuah kekhawatiran besar. Prestasi siswa merupakan hasil proses pembelajaran seperti pengetahuan dan keterampilan serta kemampuan yang berkembang pada proses pembelajaran (Hawkins et al., 2007; Nitko \& Brookhart, 2011; Phye, 1997). Jika berpedoman pada definisi tersebut, maka dapat disimpulkan bahwa bahwa proses pembelajaran yang ada saat ini belum mampu untuk meningkatkan prestasi belajar matematika siswa di Indonesia, sehingga siswa tidak dapat menguasai dan memahami konsepkonsep matematika dengan baik. Selain pemahaman konsep-konsep matematika, kemampuan untuk menerapkan konsep-konsep matematika juga penting. Hal ini berhubungan dengan penerapan dan penggunaan matematika dalam kehidupan sehari-hari. Matematika dapat dijadikan alat untuk menyelesaikan masalah kehidupan sehari-hari (Pollak, 2006). Maksudnya, ketika terdapat sebuah permasalahan dalam kehidupan sehari-hari, siswa dapat menghubungkan permasalahan tersebut dengan matematika, siswa mencoba menerapkan matematika dalam menyelesaikan permasalahan tersebut.

Berbicara mengenai penerapan konsep matematika, maka sama saja dengan berbicara mengenai literasi matematika (mathematical literacy). Literasi matematika dikenalkan dalam PISA (OECD, 2009). OECD (2009) menegaskan bahwa matematika itu memiliki peran utama dalam kehidupan. Oleh sebab itu, perlu untuk mengklasifikasi literasi matematika seorang siswa. Jika literasi matematika siswa baik, maka kemampuan dalam menerapkan matematika juga dapat dikatakan baik. Literasi matematika dapat diklasifikasi dengan menguji kemampuan pemodelan matematika siswa, karena kemampuan pemodelan merupakan bagian penting dari literasi matematika itu sendiri (Henning \& Keune, 2007). Kemampuan pemodelan matematika inilah yang akan menghubungkan permasalahan sehari-hari dan dunia matematika (Greer \& Verschaffel, 2007). Hal ini menjelaskan bahwa pemodelan matematika adalah jembatan yang menghubungkan keduanya serta merupakan hal yang utama pada pembelajaran. Dengan demikian, siswa sebaiknya mempunyai kemahiran pada pemodelan matematika.

Kemampuan pemodelan adalah kemampuan siswa secara otonomi (independen) terlibat dalam proses pemodelan matematika (Blomhøj \& Jensen, 2003; Blum et al., 2007; Maaß, 2006). Proses pemodelan itu sendiri terdiri dari beberapa tahapan atau beberapa komponen seperti yang digambarkan oleh Blum (2011) pada Gambar 1. Tahap pertama dalam proses pemodelan adalah constructing. Pada tahap ini, seorang siswa harus mampu memahami permasalahan yang diberikan dengan baik (Kaiser \& Brand, 2015). Apa yang akan dikerjakan dan model situasi yang akan dikembangkan sudah ada di dalam pikiran siswa (Blum, 2011). Pada tahap ini siswa juga akan mengidentifikasi informasi (variabel-variabel) penting pada permasalahan. Tahap kedua adalah simplifying/structuring, dimana hal penting pada tahap ini berkaitan dengan terbentuknya model nyata (real model) oleh siswa (Blum, 2011). Terbentuknya model nyata ini terjadi dengan cara melakukan simplifikasi terhadap masalah yang ada. Simplifikasi dilakukan dengan cara mengidentifikasi hubungan antar variabel atau informasi yang nantinya relevan atau tidak relevan dalam menyelesaikan masalah (Greefrath \& Vorhölter, 2016). 


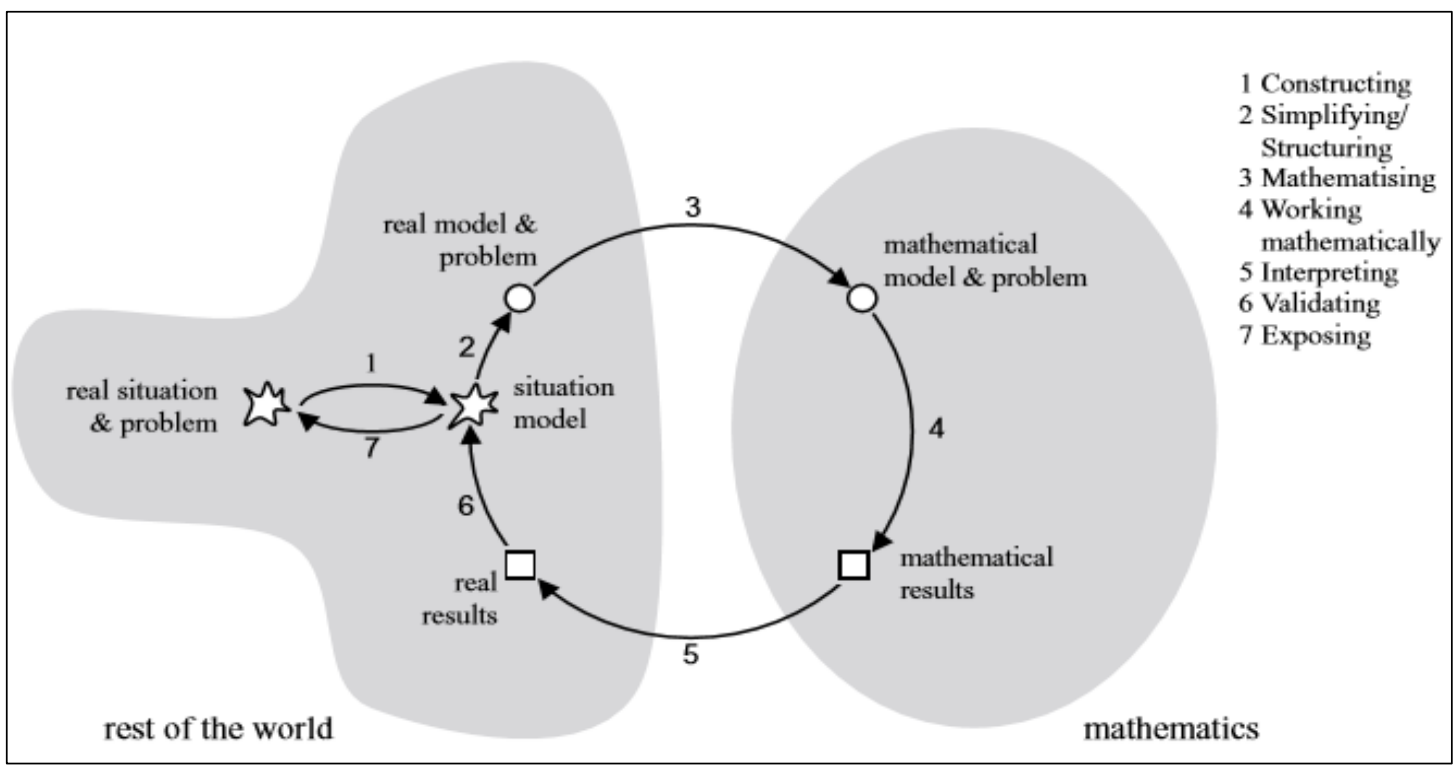

Gambar 1. Proses pemodelan matematika (Blum, 2011, p. 18)

Tahap ketiga dalam proses pemodelan adalah mathematising, yaitu tahap mengubah model nyata ke dalam model matematika (mathematical model) (Blum, 2011). Model matematika ini bentuknya berupa persamaan, gambar, diagram, dan fungsi (Greefrath \& Vorhölter, 2016). Pada tahap ini, variabel yang ada pada model nyata diubah ke dalam bentuk persamaan. Tahap keempat dari proses pemodelan adalah working mathematically. Tahap ini ditandai dengan adanya mathematical result (Blum, 2011). Pada tahap ini, siswa melakukan analisis secara matematika (Czocher, 2017). Usaha yang dapat dilakukan oleh siswa yaitu dengan cara menyelesaikan persamaanpersamaan (model matematika), siswa bekerja secara matematika seperti perkalian, pembagian, atau menggunakan metode seperti eliminasi, substitusi, dan lain sebagainya.

Tahap kelima dalam proses pemodelan adalah interpreting, yaitu siswa melakukan interpretasi pada mathematical result menjadi real result (solusi nyata) (Blum, 2011). Pada tahap ini, siswa bisa menemukan kesimpulan atau rekomendasi terbaik untuk masalah tersebut. Tahap keenam adalah validating, merupakan tahap untuk memastikan kembali variabel-variabel dalam permasalahan yang diberikan (Blum, 2011) atau memeriksa kembali model matematika yang telah dibuat (Hidiroglu \& Guzel, 2013). Hal ini dilakukan agar tidak melupakan variabel penting lainnya yang mungkin juga berguna atau berpengaruh terhadap kesimpulan atau hasil yang didapat. Pertanyaan yang dapat diajukan pada tahap ini seperti "do model and results of model give an ideal solution?" (Hidiroglu \& Guzel, 2013, p. 1203).Tahap terakhir adalah exposing, yaitu memperjelas kesimpulan atau solusi yang diperoleh (Blum, 2011). Greefrath dan Vorhölter (2016) menjelaskan bahwa pada tahap ini siswa akan menjelaskan hasil yang diperoleh kepada situasi nyata dan akhirnya memperoleh jawaban dari permasalahan yang diberikan.

Tahap-tahap pada proses pemodelan yang telah dikemukakan akan digunakan sebagai indikator untuk mengukur kemampuan pemodelan matematika siswa. Artinya, tahap-tahap yang ada dijadikan sebagai kemampuan yang harus dimiliki siswa dalam pemodelan matematika. Secara lebih jelas dapat diperhatikan pada Tabel 1.

Tabel 1. Indikator kemampuan pemodelan matematika

\begin{tabular}{ll}
\hline Komponen & Indikator \\
\hline Constructing & Mengidentifikasi informasi (variabel-variabel) penting pada \\
& permasalahan \\
Simplifying/Structuring & Mengidentifikasi hubungan antar variabel-variabel \\
Mathematising & Membuat model matematika \\
Working Mathematically & Menyelesaikan model matematika \\
Interpreting & Menginterpretasikan solusi matematika terhadap permasalahan \\
Validating & Memvalidasi solusi matematika \\
Exposing/Presenting & Menyajikan kesimpulan \\
\hline
\end{tabular}


Meningkatkan kemampuan pemodelan matematika siswa dapat dilakukan dengan latihan/penugasan yang tepat. Blum (2011) menyatakan bahwa esensi dari latihan/penugasan pemodelan yaitu untuk menerjemahkan antara dunia nyata (real world) dan matematika (mathematics). Latihan/penugasan ini mengharuskan siswa untuk mampu berpikir di luar dunia matematika dan siswa dihadapkan dengan latihan/penugasan yang berkaitan dengan kehidupan sehari-hari. Confrey (2007) menambahkan hal-hal terkait latihan/penugasan pemodelan matematika, yaitu pentingnya prior knowledge, wawasan atau pengetahuan luar sekolah, serta pengalaman dalam mengaplikasikan matematika siswa.

Latihan/penugasan untuk meningkatkan kemampuan pemodelan matematika siswa tidaklah mudah. Blum (2011) mengamati hasil PISA dan menyimpulkan bahwa latihan/penugasan pemodelan matematika adalah latihan/penugasan yang paling sulit bagi seluruh siswa di dunia, karena harus melibatkan dunia nyata. Dunia nyata (real world) yang dimaksudkan adalah dunia selain matematika seperti masyarakat sosial, budaya, dan bidang ilmu lainnya serta yang menyangkut kehidupan sehari-hari (Blum, 2002). Dengan demikian, proses pembelajaran di kelas seharusnya juga memfasilitasi siswa untuk menghubungkan matematika dengan situasi dunia nyata, salah satunya yaitu melalui pembelajaran matematika realistik.

Pembelajaran matematika realistik tidak hanya berhubungan dengan dunia nyata atau kehidupan sehari-hari saja. Kata realistik juga berkaitan dengan permasalahan apa yang dapat dibayangkan dan nyata terdapat di dalam pikiran siswa (Wijaya, 2012). Bahkan menurut Van den Heuvel-Panhuizen (2003), realistik dapat berupa cerita khayalan ataupun bentuk matematika formal sekalipun, selama itu masih dapat dibayangkan dalam pikiran siswa. Hal senada juga diungkapkan oleh Cowan (2006) bahwa pemberian situasi masalah yang dapat dibayangkan siswa tidak terbatas pada dunia nyata saja, tetapi dapat juga penggunaan situasi dunia khayalan seperti dongeng ke dunia formal matematika.

Dunia nyata sebagai sumber pengetahuan informal siswa yang nantinya akan berkembang menjadi pengetahuan formal (matematika) siswa. Perkembangan ini bisa dilakukan melalui proses pemodelan (Wijaya, 2012). Salah satu karakteristik pembelajaran matematika realistik menurut Treffers (Wijaya, 2012) adalah penggunaan model untuk matematisasi progresif. Dalam hal ini, model sebagai alat untuk menghubungkan pengetahuan matematika informal dan pengetahuan matematika formal siswa (Gravemeijer, 1999). Secara tidak langsung, pembelajaran matematika realistik dengan ide dunia nyata sebagai titik awal pembelajaran sangat mendukung untuk kemampuan pemodelan matematika siswa.

Pembelajaran matematika realistik dapat memfasilitasi pengembangan level pemodelan siswa. Menurut Gravemeijer (Wijaya, 2012) ada empat level pemodelan. Pertama adalah level situasional yang merupakan level paling bawah dan model yang berkembang masih dalam bentuk situasi masalah. Kedua adalah level referensial, pada level ini hasil pemodelan disebut sebagai model dari (model of) situasi. Ketiga adalah level general, dimana level ini mencoba mengarahkan siswa menemukan solusi atau disebut juga model untuk (model for) penyelesaian masalah. Level terakhir adalah level formal, yaitu level yang mengharuskan siswa bekerja menggunakan simbol dan representasi matematika.

Secara teori, pembelajaran matematika realistik efektif untuk meningkatkan kemampuan pemodelan matematika siswa. Sementara itu ketika ditelusuri lebih jauh berbagai referensi di Indonesia, belum banyak penelitian yang membahas kemampuan pemodelan matematika. Salah satu penelitian yang telah dilakukan yaitu penelitian Nainggolan (2009) yang menemukan bahwa pembelajaran matematika realistik memberikan pengaruh positif terhadap peningkatan kemampuan pemodelan matematika siswa. Dengan demikian, pembelajaran matematika realistik diduga dapat mengatasi permasalahan yang berkaitan dengan kemampuan pemodelan matematika siswa. Selain itu, jika dikaitkan dengan pembelajaran ekspositori, yaitu pembelajaran yang sering diterapkan guru di kelas, pembelajaran matematika realistik diduga lebih unggul dalam meningkatkan kemampuan pemodelan matematika dan prestasi belajar siswa. Dengan demikian, tujuan penelitian ini adalah untuk membandingkan keefektifan antara pembelajaran matematika realistik dan pembelajaran ekspositori sebagai pembelajaran yang sering diterapkan guru di kelas ditinjau dari kemampuan pemodelan matematika dan prestasi belajar siswa SMP.

\section{METODE}

Jenis penelitian yang dilakukan adalah penelitian eksperimen semu (quasi experiment) dan desain penelitian yang digunakan adalah pretest-posttest nonequivalent control group. Alasan pemilihan eksperimen semu dikarenakan peneliti tidak bisa melakukan pemilihan secara acak (random) individu mana yang akan dimasukkan ke dalam kelompok eksperimen dan mana individu yang masuk ke dalam kelompok kontrol (Ali, 2010). Dalam penelitian ini, 
peneliti hanya menggunakan kelompok alami yang sudah terbentuk sebelumnya, namun pemilihan kelompok untuk keperluan ini dilakukan secara acak dari beberapa kelompok alami yang sudah ada.

Penelitian ini dilaksanakan di SMP Negeri 15 Yogyakarta. Populasi penelitian adalah seluruh siswa kelas VIII SMP Negeri 15 Yogyakarta yang terdiri dari 10 kelas. Sampel dipilih secara acak dari 10 kelas yang ada, kemudian terpilihlah kelas VIII C $(n=33)$ sebagai kelas eksperimen dan kelas VIII F $(n=33)$ sebagai kelas kontrol. Kelas eksperimen mendapat perlakuan berupa pembelajaran matematika dengan menerapkan pembelajaran matematika realistik, sedangkan kelas kontrol mendapat perlakuan dengan menerapkan pembelajaran ekspositori sebagai pembelajaran yang sering diterapkan guru di kelas. Pada pembelajaran matematika realistik tahapan pembelajaran meliputi memahami masalah nyata (realistik), melakukan matematisasi horizontal, melakukan matematisasi vertikal, mengkomunikasikan, dan melakukan refleksi. Adapun pada pembelajaran ekspositori, tahapan pembelajaran secara umum meliputi pengkondisian siswa (persiapan), penjelasan materi pembelajaran (penyajian), memberikan makna terhadap materi pembelajaran (korelasi), memahami inti dari materi pembelajaran (menyimpulkan), dan mengaplikasikan materi yang telah dipelajari.

\section{Instrumen Penelitian}

Instrumen yang digunakan pada penelitian ini terdiri dari tes untuk mengukur kemampuan pemodelan dan tes untuk mengukur prestasi belajar, baik sebelum (pretest) maupun setelah perlakuan diberikan (posttest). Tes kemampuan pemodelan menggunakan soal berbentuk uraian yang terdiri dari 3 butir soal. Sementara itu, tes prestasi belajar menggunakan soal berbentuk pilihan ganda yang terdiri dari 15 butir soal. Materi yang diujikan pada tes kemampuan pemodelan dan prestasi belajar adalah perbandingan senilai dan berbalik nilai. Aspek yang diukur pada tes kemampuan pemodelan dapat dilihat pada Tabel 1. Adapun aspek yang diukur pada tes prestasi belajar meliputi ketercapaian indikator pembelajaran pada materi perbandingan senilai dan berbalik nilai, seperti mencontohkan perbandingan senilai dan berbalik nilai, menentukan persamaan perbandingan senilai dan berbalik nilai, membuat grafik perbandingan senilai dan berbalik nilai, menafsirkan grafik perbandingan senilai dan berbalik nilai, serta menentukan solusi dari masalah terkait perbandingan senilai dan berbalik nilai.

\section{Validitas dan Reliabilitas Instrumen}

Validasi butir soal pada tes kemampuan pemodelan dan prestasi belajar dilakukan melalui validitas isi, yaitu dengan meminta masukan dari ahli (expert judgement) terkait kelayakan butir soal. Validasi instrumen dilakukan oleh dua orang ahli yaitu dosen Pendidikan Matematika Universitas Negeri Yogyakarta. Kedua ahli tersebut memiliki kompetensi di bidang pendidikan matematika dan evaluasi pendidikan matematika, serta memiliki gelar Doktor. Peneliti melakukan perbaikan butir tes berdasarkan masukan kedua validator hingga butir dinyatakan layak dan valid oleh kedua validator tersebut. Setelah instrumen dinyatakan valid, selanjutnya dilakukan uji coba untuk mengestimasi reliabilitasnya. Koefisien reliabilitas instrumen pretest dan posttest prestasi belajar secara berturut-turut yaitu 0,599 dan 0,570 . Sedangkan koefisien reliabilitas instrumen pretest dan posttest kemampuan pemodelan matematika secara berturut-turut yaitu 0,762 dan 0,780. Berdasarkan hasil estimasi tersebut, masing-masing instrumen memiliki koefisien reliabilitas di atas 0,5 sehingga dapat dinyatakan bahwa instrumen reliabel untuk mengukur prestasi dan kemampuan pemodelan siswa.

\section{Teknik Analisis Data}

Data hasil penelitian yang bersumber dari tes prestasi belajar dan tes kemampuan pemodelan matematika selanjutnya dianalisis secara deskriptif dan inferensial. Analisis deskriptif dilakukan dalam rangka mendeskripsikan hasil dari proses pembelajaran yang didasarkan pada data yang diperoleh sebelum dan sesudah diberikan perlakuan untuk setiap variabel terikat yang diamati. Data yang disajikan terdiri dari banyak siswa, nilai rata-rata, standar deviasi, nilai maksimum teoritis dan minimum teoritis, nilai maksimum dan minimum yang dicapai.

Analisis inferensial dilakukan dalam rangka untuk menguji hipotesis penelitian yaitu: (1) apakah terdapat perbedaan signifikan kemampuan pemodelan matematika dan prestasi belajar siswa antara pembelajaran matematika realistik dan pembelajaran ekspositori, dan (2) pembelajaran mana yang lebih efektif ditinjau dari kemampuan pemodelan matematika dan prestasi belajar siswa. Analisis data inferensial diawali dengan menguji kesamaan vektor rata-rata kemampuan siswa pada kedua kelompok sebelum diberi perlakuan. Jika vektor rata-rata kemampuan siswa kedua kelompok berbeda signifikan, peneliti akan menghitung nilai $\mathrm{N}$-gain masing-masing siswa pada masing-masing variabel dan nilai $\mathrm{N}$-gain pada kelompok eksperimen dan kontrol akan digunakan untuk me- 
nguji perbedaan keefektifan pembelajaran matematika realistik dan pembelajaran ekspositori. Uji statistik multivariat menggunakan uji Manova Hotelling's Trace $\left(T^{2}\right)$ dilakukan untuk menguji perbedaan keefektifan kelompok eksperimen dan kelompok kontrol ditinjau dari kemampuan pemodelan matematika dan prestasi belajar siswa. Jika hasil uji statistik multivariat signifikan menolak $H_{0}$ maka analisis dilanjutkan menggunakan independent sample $t$-test untuk menyelidiki pembelajaran mana yang lebih efektif. Semua pengujian statistik dilakukan pada taraf signifikan $\alpha=0,05$.

\section{HASIL PENELITIAN}

\section{Deskripsi Kemampuan Pemodelan Matematika dan Prestasi Belajar}

Pada bagian ini disajikan data hasil tes kemampuan pemodelan matematika siswa pada kelas pembelajaran matematika realistik dan pembelajaran ekspositori, baik sebelum (pretest) maupun setelah diberi perlakuan (posttest) (lihat Tabe 2). Selain itu, pada bagian ini juga disajikan capaian siswa ditinjau dari masing-masing indikator pemodelan matematika (lihat Tabel 3). Pada Tabel 2 dapat dilihat bahwa pada kelas pembelajaran matematika realistik kemampuan pemodelan matematika siswa setelah diberi perlakuan meningkat sebesar 31 poin. Sedangkan pada kelas ekspositori peningkatan kemampuan pemodelan matematika siswa setelah diberi perlakuan hanya sebesar 26,4 poin. Hasil tersebut menunjukkan bahwa peningkatan kemampuan pemodelan siswa pada kelas pembelajaran matematika realistik lebih baik dibandingkan kelas pembelajaran ekspositori.

Tabel 2. Deskripsi kemampuan pemodelan matematika siswa

\begin{tabular}{lcccc}
\hline \multirow{2}{*}{ Statistik } & \multicolumn{2}{c}{ Pemb. matematika realistik } & \multicolumn{2}{c}{ Pembelajaran ekspositori } \\
\cline { 2 - 5 } & pretest & posttest & pretest & posttest \\
\hline$n$ & 33 & 33 & 33 & 33 \\
$M$ & 26,1 & 57,1 & 13,3 & 39,7 \\
$S D$ & 11,1 & 8,1 & 13 & 10,8 \\
Nilai minimal teoretis & 0 & 0 & 0 & 0 \\
Nilai maksimal teoretis & 100 & 100 & 100 & 100 \\
Nilai minimal & 0 & 40 & 0 & 0 \\
Nilai maksimal & 40 & 76,7 & 40 & 66,7 \\
\hline
\end{tabular}

Tabel 3. Capaian siswa ditinjau dari indikator kemampuan pemodelan matematika

\begin{tabular}{|c|c|c|c|c|c|c|c|c|}
\hline \multirow{2}{*}{ Indikator } & \multicolumn{2}{|c|}{ Nilai teoretis } & \multicolumn{3}{|c|}{ Matematika Realistik } & \multicolumn{3}{|c|}{ Ekspositori } \\
\hline & Min. & Maks. & Min. & Maks. & $M$ & Min. & Maks. & $M$ \\
\hline $\begin{array}{l}\text { Mengidentifikasi informasi } \\
\text { (variabel-variabel) penting } \\
\text { pada permasalahan }\end{array}$ & 0 & 9 & 5 & 8 & 6,5 & 0 & 8 & 3,9 \\
\hline $\begin{array}{l}\text { Mengidentifikasi hubungan } \\
\text { antar informasi (variabel- } \\
\text { variabel) }\end{array}$ & 0 & 9 & 2 & 6 & 5,2 & 0 & 6 & 3,8 \\
\hline Membuat model matematika & 0 & 9 & 4 & 7 & 5,3 & 0 & 5 & 4 \\
\hline $\begin{array}{l}\text { Menyelesaikan model } \\
\text { matematika }\end{array}$ & 0 & 12 & 4 & 10 & 6,6 & 0 & 10 & 4,6 \\
\hline $\begin{array}{l}\text { Menginterpretasikan solusi } \\
\text { matematika kepada } \\
\text { permasalahan }\end{array}$ & 0 & 12 & 4 & 10 & 6,6 & 0 & 10 & 4,6 \\
\hline $\begin{array}{l}\text { Memvalidasi solusi } \\
\text { matematika }\end{array}$ & 0 & 9 & 1 & 7 & 4,2 & 0 & 7 & 2,8 \\
\hline Menyajikan kesimpulan & 0 & 6 & 1 & 4 & 2,3 & 0 & 5 & 2,5 \\
\hline
\end{tabular}

Pada Tabel 3 dapat dilihat bahwa perolehan nilai maksimal kelas pembelajaran matematika realistik dan kelas ekspositori pada dasarnya hampir sama, kecuali pada indikator membuat model matematika dan menyajikan kesimpulan. Sementara itu, rata-rata kelas pembelajaran matematika realistik lebih tinggi dari kelas ekspositori, 
kecuali untuk indikator menyajikan kesimpulan. Pada pembelajaran ekspositori terdapat langkah pembelajaran yaitu menyimpulkan, sehingga dapat dikatakan pembelajaran ekspositori lebih baik dibandingkan dengan pembelajaran matematika realistik pada indikator menyajikan kesimpulan, tetapi selisih rata-rata kedua kelas tidak terlalu besar.

Deskripsi prestasi belajar matematika siswa sebelum (pretest) dan sesudah (posttest) perlakuan pada kelas pembelajaran matematika realistik dan pembelajaran ekspositori disajikan pada Tabel 4. Pada kelas pembelajaran matematika realistik, prestasi belajar siswa meningkat sebesar 20,2 poin setelah diberi perlakuan. Sedangkan pada kelas pembelajaran ekspositori, prestasi belajar siswa hanya meningkat sebesar 14,8 poin setelah diberi perlakuan. Hal tersebut menunjukkan bahwa peningkatan prestasi belajar matematika siswa pada kelas pembelajaran matematika realistik lebih baik dibandingkan kelas pembelajaran ekspositori.

Tabel 4. Deskripsi prestasi belajar matematika siswa

\begin{tabular}{lcccc}
\hline \multirow{2}{*}{ Statistik } & \multicolumn{2}{c}{ Pemb. matematika realistik } & \multicolumn{2}{c}{ Pembelajaran ekspositori } \\
\cline { 2 - 5 } & Pretest & Posttest & Pretest & Posttest \\
\hline$n$ & 33 & 33 & 33 & 33 \\
$M$ & 50,7 & 70,9 & 42,8 & 57,6 \\
$S D$ & 14,8 & 14,9 & 14 & 20,4 \\
Nilai minimal teoretis & 0 & 0 & 0 & 0 \\
Nilai maksimal teoretis & 100 & 100 & 100 & 100 \\
Nilai minimal & 26,7 & 40 & 6,7 & 8 \\
Nilai maksimal & 86,7 & 100 & 73,3 & 80 \\
\hline
\end{tabular}

\section{Perbedaan Keefektifan Pembelajaran Matematika Realistik dan Ekspositori}

Sebelum menguji perbedaan keefektifan pembelajaran matematika realistik dan pembelajaran ekspositori, terlebih dahulu diuji kesamaan vektor rata-rata kemampuan pemodelan matematika dan prestasi belajar siswa sebelum diberi perlakuan (pretest). Hasil analisis data menunjukkan bahwa secara simultan kemampuan pemodelan matematika dan prestasi belajar siswa sebelum diberi perlakuan berbeda signifikan, $F(2,63)=9,886 ; p<$ 0,$001 ; T^{2}=0,314$. Hasil tersebut membuktikan secara statistik bahwa kemampuan awal siswa kelas pembelajaran matematika realistik dan kelas pembelajaran konvensional tidak sama. Karena adanya perbedaan kemampuan awal kedua kelas, maka untuk menguji apakah terdapat perbedaan kemampuan kedua kelas setelah perlakuan digunakan data $\mathrm{N}$-gain. Rata-rata $\mathrm{N}$-gain pada kelas pembelajaran matematika realistik dan kelas pembelajaran ekspositori disajikan pada Tabel 5.

Tabel 5. Rata-rata (M) N-gain prestasi belajar dan kemampuan pemodelan matematika

\begin{tabular}{lcc}
\hline Variabel & Pemb. matematika realistik & Pembelajaran ekspositori \\
\hline Prestasi belajar matematika & 0,405 & 0,245 \\
Kemampuan pemodelan matematika & 0,404 & 0,285 \\
\hline
\end{tabular}

Untuk menguji apakah rata-rata $\mathrm{N}$-gain pada kelas pembelajaran matematika realistik dan pembelajaran ekspositori berbeda signifikan, analisis statistik multivariat dengan tes Hotelling's Trace dilakukan. Hasil analisis tersebut menunjukkan bahwa rata-rata $\mathrm{N}$-gain prestasi belajar dan kemampuan pemodelan matematika antara kelas pembelajaran matematika realistik dan pembelajaran ekspositori berbeda signifikan, $F(2,63)=5,261 ; p=$ 0,$008 ; T^{2}=0,167$. Berdasarkan hasil tersebut, dapat disimpulkan bahwa secara simultan peningkatan prestasi belajar dan kemampuan pemodelan matematika siswa antara kelas pembelajaran matematika realistik dan kelas pembelajaran ekspositori berbeda signifikan.

Selanjutnya untuk menyelidiki variabel terikat mana yang berbeda signifikan, dilakukan uji lanjut (post-hoc). Uji lanjut yang dilakukan merupakan uji satu pihak (one-tailed) dimana peneliti menghipotesiskan bahwa prestasi belajar dan kemampuan pemodelan matematika siswa pada kelas pembelajaran matematika realistik (kelompok eksperimen) lebih unggul dibandingkan kelas pembelajaran ekspositori (kelompok kontrol). Ringkasan hasil uji lanjut menggunakan independent sample t-test untuk variabel prestasi belajar matematika dan kemampuan pemodelan matematika disajikan pada Tabel 6. 
Tabel 6. Ringkasan hasil uji lanjut (post-hoc) kelompok eksperimen vs. kelompok kontrol

\begin{tabular}{lccc}
\hline Variabel & $t(64)$ & $t(0,05,64)$ & Keputusan \\
\hline Prestasi belajar matematika & 2,2 & 1,7 & $H_{0}$ ditolak \\
Kemampuan pemodelan matematika & 3,1 & 1,7 & $H_{0}$ ditolak \\
\hline
\end{tabular}

Hasil analisis pada Tabel 6 menunjukkan bahwa prestasi belajar matematika siswa pada kelas pembelajaran matematika realistik lebih baik daripada kelas pembelajaran ekspositori, $t(64)=2,2 ; p<0,05$. Selain itu, hasil analisis pada Tabel 6 juga menunjukkan bahwa kemampuan pemodelan matematika siswa pada kelas pembelajaran matematika realistik lebih baik daripada kelas pembelajaran ekspositori. Dengan demikian, dapat disimpulkan bahwa pembelajaran matematika realistik lebih efektif dibandingkan pembelajaran ekspositori ditinjau dari prestasi belajar dan kemampuan pemodelan matematika siswa.

\section{PEMBAHASAN}

Hasil penelitian menunjukkan bahwa pembelajaran matematika realistik lebih baik (unggul) dari pembelajaran ekspositori ditinjau dari kemampuan pemodelan matematika dan prestasi belajar. Hal tersebut disebabkan karena aktivitas pada pembelajaran matematika realistik sangat membantu siswa dalam mengonstruksi pengetahuannya. Hal ini senada dengan pendapat Bray dan Tangney (2016) bahwa pada pembelajaran yang memberikan siswa permasalahan realistik yang dapat memberikan kebermaknaan kepada siswa itu sendiri. Kebermaknaan ini diharapkan memberikan keinginan siswa untuk belajar matematika. Kemudian siswa menjadi terbiasa ketika bertemu dengan soal yang berbentuk permasalahan realistik, terutama ketika mengerjakan soal-soal yang berkaitan dengan prestasi belajar dan kemampuan pemodelan matematika.

Selain itu pembelajaran matematika realistik dalam langkah-langkah pembelajarannya terdapat proses matematisasi vertikal dan matematisasi horizontal. Dalam kedua proses matematisasi tersebut terdapat aktivitas pemodelan yang dapat melatihkan kemampuan pemodelan matematika siswa. Hal senada diungkapkan Kaiser dan Schwarz (2010) bahwa kemampuan pemodelan akan berkembang melalui proses pemodelan yang diterapkan dalam pembelajaran matematika. Oleh karena itu, untuk mendapatkan hasil yang lebih maksimal dan tingkat efektivitas yang lebih baik, maka diperlukan evaluasi dan perbaikan dalam menerapkan pembelajaran matematika realistik. Hal ini sejalan dengan temuan penelitian-penelitian terdahulu (misalnya, Sopia \& Wutsqa, 2015; Wahidin \& Sugiman, 2014; Zaini \& Marsigit, 2014).

Temuan penelitian tentunya memberikan kontribusi terhadap praktik pembelajaran matematika, khususnya dalam rangka mendorong peningkatan kemampuan pemodelan matematika siswa. Sebagai upaya untuk meningkatkan kualitas pembelajaran matematika di masa yang akan datang, pendidik dapat menerapkan pembelajaran matematika realistik sebagai salah satu alternatif untuk meningkatkan kemampuan pemodelan matematika siswa. Mengingat kemampuan pemodelan matematika berperan penting terhadap kesuksesan belajar siswa, maka kemampuan tersebut perlu terus dijadikan sebagai salah satu fokus dalam pembelajaran matematika. Dengan demikian, temuan penelitian ini yang sekaligus telah memberikan bukti empiris terkait efektivitas pembelajaran matematika realistik, tetap dapat dijadikan sebagai rujukan bagi pendidik, pengembang kurikulum, dan pengambil kebijakan untuk peningkatan kualitas pendidikan di masa yang akan datang, khususnya pada pendidikan matematika.

Meskipun penelitian ini berhasil membuktikan secara empiris bahwa pembelajaran matematika realistik efektif, dimana temuan tersebut telah sesuai dengan yang diharapkan, namun terdapat beberapa keterbatasan dalam penelitian ini. Pertama, ukuran sampel yang digunakan dalam penelitian tergolong kecil, sehingga temuan penelitian tidak cukup kuat untuk digeneralisasi secara lebih luas. Kedua, desain penelitian belum melibatkan variabel moderator yang diduga ikut mempengaruhi keefektifan pembelajaran pada kelompok eksperimen dan kontrol, seperti tingkat motivasi belajar siswa, kecemasan siswa terhadap matematika, dan lain sebagainya. Keterbatasan-keterbatasan tersebut berimplikasi bagi peluang penelitian di masa yang akan datang. Dengan demikian, ke depannya diharapkan peneliti lain dapat mereplikasi penelitian serupa dengan melibatkan populasi dan sampel yang lebih luas, sehingga temuan penelitian nantinya dapat semakin memperkuat temuan pada penelitian ini. $\mathrm{Di}$ samping itu, perlu juga dilakukan penelitian serupa dengan melibatkan variabel moderator yang telah kami sebutkan sebelumnya. Hasil dari penelitian tersebut diharapkan dapat memberikan kontribusi untuk perbaikan kualitas pembelajaran realistik pada tatanan teoretis dan praktis. 


\section{SIMPULAN}

Penelitian ini membuktikan bahwa terdapat perbedaan keefektifan antara pembelajaran matematika realistik dan pembelajaran ekspositori ditinjau dari peningkatan kemampuan pemodelan matematika dan prestasi belajar siswa kelas VIII SMP. Penelitian juga menemukan bahwa pembelajaran matematika realistik lebih baik (unggul) dari pembelajaran ekspositori ditinjau dari peningkatan kemampuan pemodelan matematika maupun prestasi belajar matematika siswa kelas VIII SMP. Berdasarkan hasil penelitian, peneliti menyarankan beberapa hal. Pertama, sekolah sebaiknya mengadakan bimbingan untuk guru matematika dalam menguasai dan mengembangkan pembelajaran matematika realistik dengan harapan guru memiliki keahlian dan dapat menerapkan pembelajaran matematika realistik sebagai alternatif lain dalam mengajarkan matematika kepada siswa. Kedua, peneliti lain jika hendak melakukan penelitian sejenis, sebaiknya mempersiapkan diri dengan baik dan dapat mengatur waktu penelitian agar maksimal dalam menerapkan pembelajaran matematika realistik, diperlukan jumlah pertemuan tatap muka dengan siswa di kelas yang lebih banyak dari penelitian ini. Selain itu, sebaiknya penelitian tidak dilakukan hanya pada satu sekolah, namun dilakukan pada banyak sekolah dengan tingkat prestasi sekolah yang berbeda.

\section{DAFTAR PUSTAKA}

Ali, M. (2010). Metodologi dan aplikasi riset pendidikan. Pustaka Cendikia.

Blomhøj, M., \& Jensen, T. H. (2003). Developing mathematical modelling competence: conceptual clarification and educational planning. Teaching Mathematics and Its Applications, 22(3), 123-139. https://doi.org/10.1093/teamat/22.3.123

Blum, W. (2002). ICMI study 14 applications and modelling in mathematics education - discussion document. Educational Studies in Mathematics, 51, 149-171. https://doi.org/10.1023/A:1022435827400

Blum, W., Henn, H.-W., Galbraith, P. L., \& Niss, M. (Eds.) (2007). Modelling and applications in mathematics education: The 14 th ICMI study. Springer. https://doi.org/10.1007/978-0-387-29822-1

Blum, W. (2011). Can modelling be taught and learnt? some answers from empirical research. In G. Kaiser, W. Blum, R. B. Ferri, \& G. Stillman (Eds.), Trends in teaching and learning of mathematical modelling ICTMA 14 (pp. 1530). Springer. https://doi.org/10.1007/978-94-007-0910-2_3

Bray, A., \& Tangney, B. (2016). Enhancing student engagement through the affordances of mobile technology: A 21st century learning perspective on realistic mathematics education. Mathematics Education Research Journal, 28, 173-197. https://doi.org/10.1007/s13394-015-0158-7

Confrey, J. (2007). Epistemology and modelling-overview. In W. Blum, P. L. Galbraith, H.-W. Henn, \& M. Niss (Eds.), Modelling and applications in mathematics education (pp. 125-128). Springer. https://doi.org/10.1007/97894-007-0910-2_3

Cowan, P. (2006). Teaching mathematics: A handbook for primary and secondary school teacher. Routledge.

Czocher, J. A. (2017). Mathematical modeling cycles as a task design heuristic. The Mathematics Enthusiast, 14(1), 129-140. https://scholarworks.umt.edu/tme/vol14/iss1/9/

Gravemeijer, K. (1999). How emergent models may foster the constitution of formal mathematics. Mathematical Thinking and Learning, 1(2), 155-177. https://doi.org/10.1207/s15327833mt|0102_4

Greefrath, G., \& Vorhölter, K. (2016). Teaching and learning mathematical modelling. Springer. https://doi.org/10.1007/978-3-319-45004-9

Greer, B., \& Verschaffel, L. (2007). Modelling competencies-Overview. In W. Blum, P. L. Galbraith, H.-W. Henn, \& M. Niss (Eds.), Modelling and applications in mathematics education (pp. 218-224). Springer. https://doi.org/10.1007/978-94-007-0910-2_3

Hawkins, K. B., Florian, L., \& Rouse, M. (2007). Achievement and inclusion in schools. Routledge. 
Henning, H., \& Keune, M. (2007). Levels of modelling competencies. In W. Blum, P. L. Galbraith, H.-W. Henn, \& M. Niss (Eds.), Modelling and applications in mathematics education (pp. 225-232). Springer. https://doi.org/10.1007/978-94-007-0910-2_3

Hidiroglu, Ç. N., \& Guzel, E. B. (2013). Conceptualization of approaches and thought processes emerging in validating of model in mathematical modeling in technology aided environment. Educational Sciences: Theory \& Practice, 13(4), 2499-2506. https://doi.org/10.12738/estp.2013.4.1932

Kaiser, G., \& Brand, S. (2015). Modelling competencies: Past development and further perspectives. In G. A. Stillman, W. Blum, \& M. S. Biembengut (Eds.), Mathematical modelling in education research and practice (pp. 129-149). Springer. https://doi.org/10.1007/978-3-319-18272-8_10

Kaiser, G., \& Schwarz, B. (2010). Authentic modelling problems in mathematics education - examples and experiences. Journal for Didactics of Mathematics, 31, 51-76. https://doi.org/10.1007/s13138-010-0001-3

Maaß, K. (2006). What are modelling competencies. ZDM - Mathematics Education, 38, 113-142. https://doi.org/10.1007/BF02655885

Mullis, I. V., Martin, M. O., Foy, P., \& Arora, A. (2012). TIMSS 2011 international results in mathematics. TIMSS \& PIRLS International Study Center, Lynch School of Education. https://timssandpirls.bc.edu/timss2011/downloads/t11_ir_mathematics_fullbook.pdf

Nainggolan, P. (2009). Pengaruh pendekatan matematika realistik dan motivasi belajar siswa terhadap kemampuan pemodelan matematika siswa smp di Lubuk Pakam TP. 2008/2009 [Master's thesis, Universitas Negeri Medan]. http://digilib.unimed.ac.id/id/eprint/2704

Nitko, A. J., \& Brookhart, S. M. (2011). Educational assessment of students. Pearson Education.

OECD. (2009). Learning mathematics for life: A perspective from PISA. OECD Publishing. https://doi.org/10.1787/9789264075009-en

OECD. (2010). PISA 2009 Results: Executive summary. OECD Publishing. https://doi.org/10.1787/97892640914502-en.

OECD. (2014). PISA 2012 results: What students know and can do. OECD Publishing. https://doi.org/10.1787/9789264208780-en.

Phye, G. D. (1997). Handbook of classroom assessment learning, achievement, and adjustment. Academic Press.

Pollak, H. (2006). Modelling in mathematics classrooms: Reflections on past developments and the future. ZDMMathematics Education, 38, 178-195. https://doi.org/10.1007/BF02655888

Puspendik. (2014). Laporan hasil ujian nasional tahun pelajaran 2013-2014 [Software]. Balitbang Kemdikbud RI.

Puspendik. (2015). Laporan hasil ujian nasional tahun pelajaran 2014-2015 [Software]. Balitbang Kemdikbud RI.

Puspendik. (2016). Laporan hasil ujian nasional tahun pelajaran 2015-2016 [Software]. Balitbang Kemdikbud RI.

Sopia, H. F., \& Wutsqa, D. U. (2015). Keefektifan pendekatan realistik ditinjau dari prestasi belajar, kemampuan pemecahan masalah, dan kepercayaan diri matematika. Pythagoras: Jurnal Pendidikan Matematika, 10(2), 146-154. https://doi.org/10.21831/pg.v10i2.9139

Van den Heuvel-Panhuizen, M. V. (2003). The didactical use of model in realistic mathematics education: An example from longitudinal trajectory on percentage. Educational Studies in Mathematics, 54, 9-35. https://doi.org/10.1023/B:EDUC.0000005212.03219.dc

Wahidin, W., \& Sugiman, S. (2014). Pengaruh pendekatan PMRI terhadap motivasi berprestasi, kemampuan pemecahan masalah, dan prestasi belajar. Pythagoras: Jurnal Pendidikan Matematika, 9(1), 99-109. https://doi.org/10.21831/pg.v9i1.9072

Wijaya, A. (2012). Pendidikan matematika realistik suatu alternatif pendekatan pembelajaran matematika. Graha IImu. 
PYTHAGORAS: Jurnal Pendidikan Matematika, 15 (1), 2020 - 110

Eki Rahmad, Ariyadi Wijaya

Zaini, A., \& Marsigit. (2014). Perbandingan keefektifan pembelajaran matematika dengan pendekatan matematika realistik dan konvensional ditinjau dari kemampuan penalaran dan komunikasi matematik siswa. Jurnal Riset Pendidikan Matematika, 1(2), 152-163. https://doi.org/10.21831/jrpm.v1i2.2672 